\title{
ANALISIS FRAUD TENDENCY MELALUI PENDEKATAN PENTAGON FRAUD: UNETHICAL BEHAVIOR SEBAGAI MEDIATOR
}

\author{
Reskino \\ reskino@uinjkt.ac.id \\ UIN Syarif Hidayatullah Jakarta \\ Harnovinsah \\ Universitas Mercu Buana \\ Siti Hamidah \\ UIN Syarif Hidayatullah Jakarta
}

\begin{abstract}
This study investigates fraud tendency through with unethical behavior as a mediator. The empirical study involves the use of quantitative research. Data was collected through structured questionnaires from 118 respondents of financial staff working in Islamic banking and Islamic insurance in DKI Jakarta. The data analysis method that used as Partial Least Square (PLS)-SEM with the help of data analysis tool SmartPLS 3.0. The findings from this research shows a significant relationship between competence and individual morality on unethical behavior. Competence and individual morality does not have significant effect on fraud tendency. Unethical behavior have significant effect on fraud tendency. Furthermore, competence and individual morality have significant effect on fraud tendency through unethical behavior. This study concludes that a person has sufficient competence, it will keep him away from unethical behavior so that the fraud tendency can be avoided. Furthermore, the individual morality of Islamic banking and Islamic insurance financial staff can prevent unethical behavior so that the fraud tendency can be significantly minimized.
\end{abstract}

Key words: competence, individual morality, unethical behavior, fraud tendency.

\begin{abstract}
ABSTRAK
Studi ini mengkaji kecenderungan fraud melalui perilaku tidak etis sebagai mediator. Penelitian ini merupakan penelitian kuantitatif. Data dikumpulkan melalui kuesioner terstruktur dari 118 responden staf keuangan yang bekerja di perbankan syariah dan asuransi syariah di DKI Jakarta. Metode analisis data yang digunakan adalah Partial Least Square (PLS) -SEM dengan bantuan alat analisis data SmartPLS 3.0. Temuan dari penelitian ini menunjukkan adanya pengaruh yang signifikan antara kompetensi dan moralitas individu terhadap perilaku tidak etis. Kompetensi dan moralitas individu tidak berpengaruh signifikan terhadap kecenderungan kecurangan. Perilaku tidak etis berpengaruh signifikan terhadap kecenderungan kecurangan. Selanjutnya kompetensi dan moralitas individu berpengaruh signifikan terhadap kecenderungan kecurangan melalui perilaku tidak etis. Penelitian ini menyimpulkan bahwa apabila seseorang memiliki kompetensi yang cukup, maka akan dapat menjauhkannya dari perilaku tidak etis sehingga kecenderungan kecurangan dapat dihindari. Selain itu, moralitas individu pada staf perbankan syariah dan staf keuangan asuransi syariah dapat mencegah perilaku tidak etis sehingga kecenderungan fraud dapat diminimalisir secara signifikan.
\end{abstract}

Kata kunci: kompentensi, moral individual, perilaku tidak beretika, tendensi fraud.

\section{PENDAHULUAN}

Dunia bisnis selalu dibayangi oleh fraud risk yang berasal dari berbagai sumber yang terkait dengan perusahaan, meskipun sebagian besar fraud yang dilakukan oleh sumber eksternal biasanya bersifat masif dan serius. Fraud yang terjadi sebagian besar dilakukan bekerja sama dengan pihak internal perusahaan. Mayoritas kasus fraud yang terjadi di perusahaan, terutama diakibatkan 
karena adanya keterlibatan pihak manajemen yang akan berdampak pada kredibilitas dan kegagalan dalam mencapai tujuan perusahaan.

Kasus kecurangan di bidang keuangan dan akuntansi bagaikan suatu fenomena yang tiada habisnya. Data yang dikeluarkan oleh Association of Certified Fraud Examiners (ACFE) dalam Report to The Nations 2020 Global Study on Occupational Fraud and Abuse memaparkan bahwa sepanjang tahun 20182019 terdapat 2.504 kasus kecurangan dari 125 negara, 198 kasus di antaranya berasal dari negara di wilayah Asia-Pasifik dan Indonesia menjadi negara dengan jumlah kasus kecurangan terbanyak di Asia-Pasifik, yakni 36 kasus. Selain itu, ACFE (2020) juga menyebutkan bahwa industri keuangan dan perbankan adalah industri dengan jumlah kasus fraud terbanyak, yakni sebesar 386 kasus dengan rata-rata kerugian mencapai $\$ 100,000$.

Pada awal tahun 2020, belum lama setelah kasus gagal bayar Jiwasraya mencuat, industri keuangan di Indonesia kembali dihebohkan dengan dugaan korupsi PT Asuransi Sosial Angkatan Bersenjata Republik Indonesia (Asabri). Mahfud MD selaku Menteri Koordinator Bidang Politik, Hukum, dan Keamanan (Menko Polhukan), menilai kerugian yang ditimbulkan dari kasus tersebut mencapai Rp10 triliun (Idris, 2020). Hal ini disebabkan karena adanya kekeliruan dalam penempatan investasi pada 14 emiten yang mengalami penurunan harga saham (Prastiwi, 2020).

Di sisi lain, industri asuransi syariah mampu tumbuh saat banyaknya kasus kecurangan yang terjadi pada beberapa perusahaan asuransi konvensional. Bahkan pada pandemi ini, berdasarkan data OJK, hingga Maret 2020 kontribusi (premi) bruto asuransi jiwa syariah tumbuh mencapai Rp3,31 triliun. Nilai tersebut meningkat 5,08\% dibandingkan kuartal pertama 2019 senilai Rp3,15 triliun (Winarto, 2020). Namun, bukan berarti asuransi syariah tak luput dari polemik keuangan. Seperti yang terjadi pada PT Asuransi Syariah Mubarakah (ASM) yang diputus pailit pada 6 September 2016. ASM dinilai tidak bisa menjaga kesehatan keuangan (solvabilitas) dalam menjalankan usahanya untuk memenuhi kewajiban para pemegang polis seperti yang diatur dalam Pasal 11 ayat (1a) dan (1b) UndangUndang Nomor 2 Tahun 1992 tentang Perasuransian (Kartika, 2018).

Sektor perbankan di Indonesia pun tak lepas dari sejumlah kasus kecurangan (Meliana dan Hartono, 2019). Salah satunya yang terjadi pada tahun 2015, relation manager Bank Permata melakukan penggelapan dana sebesar Rp29 miliar milik 17 nasabah (Toyudho, 2015). Kemudian pada tahun 2017, Bank Pembangunan Daerah Jawa Barat dan Banten (BJB) Syariah diduga menyalurkan kredit fiktif senilai Rp548 miliar (Arief, 2019). Selain itu pada tahun 2019, adanya penangkapan pegawai Bank Syariah Mandiri di Lhokseumawe karena terbukti melakukan pencurian uang kas senilai Rp19 juta (Ika, 2019).

Adanya kasus-kasus tersebut membuktikan bahwa tidak ada jaminan perbankan syariah dapat bebas dari tindakan fraud. Padahal perbankan menjadi salah satu lembaga keuangan yang dipercayai masyarakat dan memegang peranan penting dalam roda perekonomian, khususnya perbankan syariah yang sudah seyogianya menjunjung tinggi nilai-nilai Islam. Namun pada faktanya, masih terdapat beberapa kasus yang merugikan masyarakat maupun entitas perbankan itu sendiri.

Etika adalah prinsip dan moral nilainilai yang mengatur perilaku orang atau kelompok yang terkait dengan apa yang benar atau salah. Etika menentukan sejauh mana sesuatu dalam perilaku dan keputusan membuat dianggap benar dan salah, baik dan buruk (Hardi et al., 2018; Fauziah \& Murharsito, 2019). Etika terlihat pada perilaku manusia, prinsip moral, dan usaha untuk memisahkan yang baik dari yang buruk. Salah satu faktor di balik banyaknya kasus penyimpangan yang terjadi di 
Indonesia disebabkan oleh unethical behavior (Fauwzi, 2011). Unethical behavior dapat seketika muncul dikarenakan rasa tidak puas atau kecewa dengan kompensasi yang diberikan oleh perusahaan atau lemahnya pengendalian yang dapat mendorong seseorang berperilaku tidak etis sehingga berdampak pada terjadinya fraud. Tetapi menurut Rae dan Subramaniam (2008), seperangkat aturan dapat menekan unethical behavior sehingga tidak akan mempengaruhi fraud tendency. Dampak dari perilaku tidak etis tersebut dapat memiliki konsekuensi yang tidak diinginkan stakeholders.

Faktor lain yang dapat mempengaruhi seseorang untuk melakukan fraud tendency adalah competence. Competence dibutuhkan guna memanfaatkan celah dan kelemahan sistem untuk melakukan tindakan menyimpang (Oktavia, 2018). Namun, pendapat yang berbeda disampaikan oleh Siregar dan Hamdani (2018) yang menyatakan bahwa fraud tendency tidak dipengaruhi oleh competence.

Selain itu, individual morality menjadi salah satu faktor yang mempengaruhi perilaku seseorang dalam melakukan fraud tendency. Menurut Fauwzi (2011), kematangan moral menjadi dasar dan pertimbangan dalam merancang tanggapan dan sikap terhadap isu-isu etis, sehingga moralitas menjadi hal penting yang berpengaruh terhadap tindakan yang diambil oleh seseorang. Fraud sangat dipengaruhi oleh lingkungan sehingga juga bisa terjadi pada karyawan maupun manajemen (Said et al., 2017; Sujeewa et al., 2018; Zuberi dan Mzenzi, 2019). Di sisi lain, Lestari dan Prasetyono (2017) memaparkan bahwa tidak terdapat perbedaan antara individu dengan moralitas tinggi maupun moralitas rendah dalam melakukan fraud tendency.

Berdasarkan paparan di atas, peneliti tertarik untuk melakukan penelitian mengenai analisis determinan fraud tendency dengan unethical behavior sebagai mediator. Penelitian ini diharapkan, dapat memberikan kontribusi bagi perbankan syariah dan asuransi syariah di Indonesia. Hasil peneliti- an ini dapat digunakan bagi industri perbankan dan asuransi syariah, untuk dapat meningkatkan kemampuannya dalam mencegah dan meminimalisir fraud tendency, dengan meningkatkan berbagai faktor internal perusahaan seperti, competence dan individual morality.

\section{TINJAUAN TEORETIS}

\section{Agency Theory}

Konsep dasar dari teori agensi yaitu hubungan kerja sama antar pihak pemegang saham (principal) dan manajemen (agent) (Jensen dan Meckling, 1976). Ketika principal dan agent memiliki pandangan yang berbeda, maka akan memicu conflict of interest. Principal berkepentingan untuk mendapatkan hasil yang maksimal dari dana yang sudah diinvestasikan. Sedangkan agent berusaha memenuhi kepentingan pribadinya untuk mendapatkan insentif atas dana yang dikelolanya dalam perusahaan. Hal ini akan menyebabkan terjadinya asimetri informasi. Asimetri informasi terjadi karena distribusi informasi yang tidak seimbang antara principal dan agent. Dalam hal ini, principal harus memiliki dan memperoleh informasi yang dibutuhkan untuk mengukur kinerja agent, tetapi kenyataannya, tidak semua informasi untuk mengukur prestasi tersebut akan diperoleh oleh principal dari pihak agent. Hal tersebut dapat menimbulkan agency problem, salah satunya asimetri informasi yang mana akan berdampak pada terjadinya fraud tendency.

\section{Attribute Theory}

Attribute theory merupakan teori yang menjelaskan tentang perilaku seseorang yang dicetuskan oleh Heider (1958). Teori ini menjelaskan bahwa terdapat hubungan antara perilaku dengan sikap dan karakteristik individu, maka bisa disimpulkan bahwa dengan melihat perilaku akan dapat diketahui sikap dan karakteristik individu tersebut, hingga dapat memprediksi perilaku individu dalam menghadapi situasi tertentu. Teori ini juga mengacu tentang faktor yang mempengaruhi perilaku se- 
seorang, yakni atribusi internal, misalnya sifat, karakter, sikap, ataupun atribusi eksternal, misalnya tekanan situasi atau keadaan tertentu. Selain itu, teori ini juga menganalisis tentang apa pengaruhnya terhadap perilaku individu di masa mendatang.

\section{Fraud Pentagon Theory}

Teori ini dikembangkan oleh Howarth (2011). Selain faktor pressure (tekanan), opportunity (peluang), dan rationalization (rasionalisasi), fraud pentagon theory mengembangkan risk factor capability menjadi competence (kompetensi) serta menambahkan satu risk factor, yakni arrogance (arogansi) sebagai faktor yang dapat mempengaruhi seseorang untuk melakukan fraud. Kompetensi adalah kemampuan karyawan untuk mengabaikan pengendalian internal, mengembangkan penyembunyian strategi, dan mengendalikan situasi sosial untuk keuntungan pribadinya (Howarth, 2011). Menurut Howarth (2011), arogansi adalah sikap superioritas atas hak yang dimiliki dan merasa pengendalian internal atau kebijakan perusahaan tidak berlaku untuk dia.

Dalam pikirannya, mereka tidak akan terdeteksi dalam melakukan kecurangan, karena mereka sangat memahami sistem pengendalian internal perusahaan. Sebagian besar tindakan fraud yang dilakukan tidak berdampak ekonomi pada mereka, tapi dorongan ego, status dan kesombonganlah yang menyebabkan mereka melakukan fraud.

\section{Fraud Tendency}

Fraud adalah tindakan curang atau tindakan tidak jujur, yang dilakukan oleh seseorang atau entitas dan dapat mengakibatkan merugikan bagi entitas atau pihak lain (Guelpa et al., 2017). Fraud tendency merupakan keinginan dalam melakukan suatu tindakan untuk memperoleh keuntungan dengan cara yang tidak jujur sehingga dapat merugikan pihak lain seperti menutupi kebenaran, penipuan, manipulasi yang dapat berupa salah saji atas laporan keuangan, korupsi, dan penyalahgunaan aset (Hasanudin dan Pangayow, 2016).

\section{Unethical Behavior}

Menurut Griffin dan Ronald (2006), unethical behavior adalah perilaku yang tidak sesuai dengan norma-norma sosial yang diterima secara umum, sehubungan dengan tindakan yang tidak bermanfaat atau yang membahayakan. Gabungan motif, peluang, dan sarana dapat menciptakan bahaya etika yang meningkatkan probabilitas seseorang berperilaku tidak etis (Pendse, 2012).

\section{Competence}

Competence merupakan karakteristik dasar individu yang berkaitan dengan efektivitas kinerja individu yang memiliki hubungan kausal atau sebab-akibat dengan kriteria yang dijadikan acuan di tempat kerja atau pada situasi tertentu (Spencer dan Spencer, 1993). Sementara itu menurut Howarth (2011) competence adalah kemampuan karyawan untuk mengabaikan control internal, mengembangkan strategi dan mengontrol situasi sosial untuk kepentingan pribadinya.

\section{Individual Morality}

Individual morality mengacu pada konsep yang mendefinisikan tindakan sehubungan dengan sifat nilai, sehingga moralitas terkait dengan kualitas perbuatan manusia dalam konteks masyarakat yang memiliki struktur budaya, sosial, politik, dan ekonomi tertentu (Wiranata, 2005). Seseorang dapat dikatakan bermoral jika tindakan dan perilakunya mencerminkan moralitas, dalam arti orang yang dapat membedakan mana hal yang baik dan buruk (Kusumastuti dan Meiranto, 2012). Sedangkan Putri dan Irwandi (2016), menjelaskan pentingnya moral pada masing-masing individu sehingga dapat dengan mudah mencegah perilaku fraud. Nilai moral akan membantu seseorang melihat apa yang benar dan salah dalam situasi yang berbeda (Wicaksono dan Urumsah, 2017; Setiawan, 2018). 


\section{Pengembangan Hipotesis}

Hasil penelitian Oktavia (2018) me nyebutkan bahwa competence berpengaruh signifikan terhadap unethical behavior. Dengan etika dan norma-norma yang berlaku, kompetensi akan mencegah perilaku tidak etis. Hal ini sejalan dengan hasil penelitian Mondal (2013) dan Susanto (2016) yang menyebutkan bahwa competence berpengaruh terhadap perilaku etis maupun tidak etis. Kompetensi mempengaruhi praktik dan perilaku etika pada tempat kerja, yang mana dipengaruhi oleh hukum dan peraturan. Berdasarkan uraian tersebut, maka hipotesis yang dirumuskan dalam penelitian ini adalah:

$\mathrm{H}_{1}$ : Competence berpengaruh secara signifikan terhadap unethical behavior

Hasil penelitian Pratiwi et al. (2016) dan Nisak dan Aeni (2017) menjelaskan bahwa individual morality berpengaruh signifikan terhadap unethical behavior. Kepedulian positif dari lingkungan kerja sangat diperlukan dalam membangun perilaku etika. Namun, hal tersebut tidak sejalan dengan penelitian Yulianti et al. (2016) yang menunjukkan hasil bahwa individual morality tidak berpengaruh terhadap unethical behavior. Tidak berpengaruhnya individual morality terhadap unethical behavior disebabkan karena individu menganggap dirinya sudah berada pada tahap moralitas yang tinggi tetapi tindakannya belum bisa terealisasi dengan baik. Berdasarkan ketidakkonsistenan hasil tersebut, maka hipotesis yang dirumuskan dalam penelitian ini adalah:

$\mathrm{H}_{2}$ : Individual morality berpengaruh secara signifikan terhadap unethical behavior

Hasil penelitian Dorminey et al. (2012) dan Oktavia (2018) menjelaskan bahwa competence berpengaruh signifikan terhadap kecurangan. Seseorang harus memiliki pengetahuan yang cukup untuk memahami dan mengeksploitasi kelemahan sistem pengendalian internal untuk melakukan kecurangan. Namun, hal tersebut tidak didukung oleh hasil penelitian Siregar dan
Hamdani (2018) dan Novita (2019) menunjukkan bahwa competence tidak berpengaruh terhadap fraud. Rendah maupun tingginya competence yang dimiliki para karyawan tidak akan mempengaruhi individu tersebut dalam melakukan fraud. Berdasarkan ketidakkonsistenan hasil tersebut, maka hipotesis yang dirumuskan dalam penelitian ini adalah:

$\mathrm{H}_{3}$ : Competence berpengaruh secara signifikan terhadap fraud tendency

Hasil penelitian Yulianti et al. (2016) dan Pratiwi et al. (2016) menjelaskan bahwa individual morality mempunyai hubungan terhadap fraud tendency. Semakin tinggi tahapan individual morality, semakin individu tersebut memperhatikan kepentingan yang lebih luas dan universal daripada kepentingan organisasinya semata. Namun, hal tersebut tidak sejalan dengan hasil penelitian Lestari dan Prasetyono (2017) yang menjelaskan bahwa individual morality tidak berpengaruh signifikan terhadap fraud tendency. Berdasarkan ketidakkonsistenan hasil tersebut, maka hipotesis yang dirumuskan dalam penelitian ini adalah:

$\mathrm{H}_{4}$ : Individual morality berpengaruh secara signifikan terhadap fraud tendency

Hasil penelitian Pratiwi et al. (2016), Yulianti et al. (2016), Oktavia (2018) menjelaskan bahwa unethical behavior berpengaruh terhadap fraud tendency. Semakin tinggi unethical behavior maka semakin tinggi tingkat fraud tendency. Namun, hal tersebut tidak didukung dengan hasil penelitian Meiryani et al. (2019) yang menjelaskan bahwa unethical behavior tidak berpengaruh terhadap fraud tendency. Dalam lingkungan yang lebih etis, karyawan akan cenderung mengikuti aturan perusahaan, sehingga unethical behavior dapat ditekan oleh aturan yang ada sehingga tidak akan mempengaruhi fraud tendency (Rae dan Subramaniam, 2008; Nwayanwu, 2018). Berdasarkan ketidakkonsistenan hasil tersebut, maka hipotesis yang dirumuskan dalam penelitian ini adalah: 
$\mathrm{H}_{5}$ : Unethical behavior berpengaruh secara signifikan terhadap fraud tendency

Hasil penelitian Oktavia (2018) menyebutkan bahwa unethical behavior dapat memediasi pengaruh competence terhadap fraud tendency. Competence berpengaruh terhadap unethical behavior. Hasil penelitian Dorminey et al. (2012) dan Oktavia (2018) menjelaskan bahwa competence berpengaruh terhadap fraud tendency. Namun, hal ini tidak didukung oleh hasil penelitian Siregar dan Hamdani (2018) menunjukkan bahwa competence tidak berpengaruh terhadap fraud. Hasil penelitian Pratiwi et al. (2016), Yulianti et al. (2016), Oktavia (2018) menjelaskan bahwa unethical behavior berpengaruh terhadap fraud tendency. Semakin tinggi unethical behavior maka semakin tinggi tingkat fraud tendency. Namun, hal tersebut tidak didukung dengan hasil penelitian Meiryani et al. (2019) yang menjelaskan bahwa unethical behavior tidak berpengaruh terhadap fraud tendency. Fraud bisa muncul karena competence seseorang yang berperan penting dalam perusahaan untuk melakukan fraud. Berdasarkan uraian di atas, maka hipotesis yang dirumuskan dalam penelitian ini adalah:

$\mathrm{H}_{6}$ : Competence berpengaruh secara signifikan terhadap fraud tendency melalui unethical behavior

Hasil penelitian Pratiwi et al. (2016) dan Fitri et al., (2016) menjelaskan bahwa individual morality memiliki hubungan signifikan terhadap fraud tendency melalui unethical behavior. Individu dengan individual morality yang tinggi diharapkan tidak melakukan unethical behavior yang akan berdampak pada terjadinya fraud tendency. Namun, hal tersebut tidak didukung oleh hasil penelitian Yulianti et al. (2016) yang menjelaskan bahwa tidak terdapat pengaruh antara individual morality dengan fraud tendency melalui unethical behavior. Individual morality yang baik belum dapat menekan terjadinya unethical behavior yang akan berdampak ter- hadap fraud tendency. Berdasarkan ketidak konsistenan hasil di atas, maka hipotesis yang dirumuskan dalam penelitian ini adalah:

$\mathrm{H}_{7}$ : Individual morality berpengaruh secara signifikan terhadap fraud tendency melalui unethical behavior

\section{METODE PENELITIAN Populasi dan Sampel}

Penelitian ini menggunakan metode kuantitatif dengan data primer. Populasi dalam penelitian ini adalah staf keuangan yang bekerja pada perbankan syariah dan asuransi syariah, sedangkan sampel pada penelitian ini adalah staf keuangan yang bekerja pada perbankan syariah dan asuransi syariah di wilayah DKI Jakarta. Dalam penelitian ini, metode pengambilan sampel yang digunakan adalah purposive sampling, dengan kualifikasi: (1) staf keuangan yang bekerja di perbankan syariah dan asuransi syariah wilayah DKI Jakarta; dan (2) staf keuangan yang memiliki pengalaman kerja minimal 1 tahun, karena dianggap telah memiliki pengalaman yang cukup untuk memahami internal perusahaan. Setelah dilakukan penyebaran kuesioner secara daring, diperoleh sampel sebanyak 118 responden.

\section{Pengukuran Variabel}

Dalam penelitian ini, competence diukur dengan menggunakan indikator yang dikembangkan oleh Spencer dan Spencer (1993) serta Indriani et al. (2016) dan disesuaikan dengan topik penelitian dengan menggunakan tiga indikator: (1) kompetensi intelektual; (2) kompetensi emosional; dan (3) kompetensi sosial.

Individual morality diukur dengan menggunakan indikator yang dikembangkan oleh Artini et al. (2014) dan Cohen et al. (1993) serta disesuaikan dengan topik penelitian dengan menggunakan tiga indikator: (1) relativisme; (2) idealisme; dan (3) egoisme.

Variabel unethical behavior diukur dengan menggunakan indikator yang di- 
kembangkan oleh Adelin dan Fauzihardani (2013) dan Fitri et al. (2016) serta disesuaikan dengan topik penelitian dengan menggunakan empat indikator: (1) perilaku yang menyalahgunakan kedudukan; (2) perilaku yang menyalahgunakan sumber daya organisasi; (3) perilaku yang menyalahgunakan kekuasaan; dan (4) perilaku yang tidak berbuat apa-apa.

Terakhir, fraud tendency diukur dengan menggunakan indikator yang dikembangkan oleh Aranta (2013), Ansori (2017), dan Karyono (2013) serta disesuaikan dengan topik penelitian dengan menggunakan tiga indikator: (1) kecenderungan untuk melakukan korupsi; (2) kecenderungan untuk melakukan penyalahgunaan aset; dan (3) kecenderungan untuk melakukan kecurangan laporan keuangan.

\section{Metode Analisis Data}

Metode pengujian dalam penelitian ini terdiri atas (1) statistik deskriptif; (2) uji outer model (convergent validity, discriminant vali- dity, dan reliability); (3) uji inner model ( $R$ Square, Q-Square, dan uji hipotesis); serta (4) uji efek intervening.

\section{ANALISIS DAN PEMBAHASAN Hasil Uji Statistik Deskriptif}

Hasil uji statistik deskriptif menggambarkan bahwa masing-masing variabel memiliki standar deviasi sebagai berikut: (1) competence 4,591; (2) individual morality 3,192; (3) unethical behavior 3,481; dan (4) fraud tendency 4,042. Selain itu, hasil uji statistik deskriptif menampilkan nilai rata-rata dari setiap variabel, yaitu competence 55,86; individual morality 28,08; unethical behavior 46,67; dan fraud tendency 73,08. Hal tersebut menggambarkan bahwa setiap variabel mempunyai nilai rata-rata di atas standar deviasi, sehingga menunjukkan bahwa kualitas data dalam penelitian ini baik. Berdasarkan paparan tersebut, disimpulkan bahwa ratarata tanggapan responden untuk variabel competence, individual morality, unethical behavior, dan fraud tendency adalah setuju.

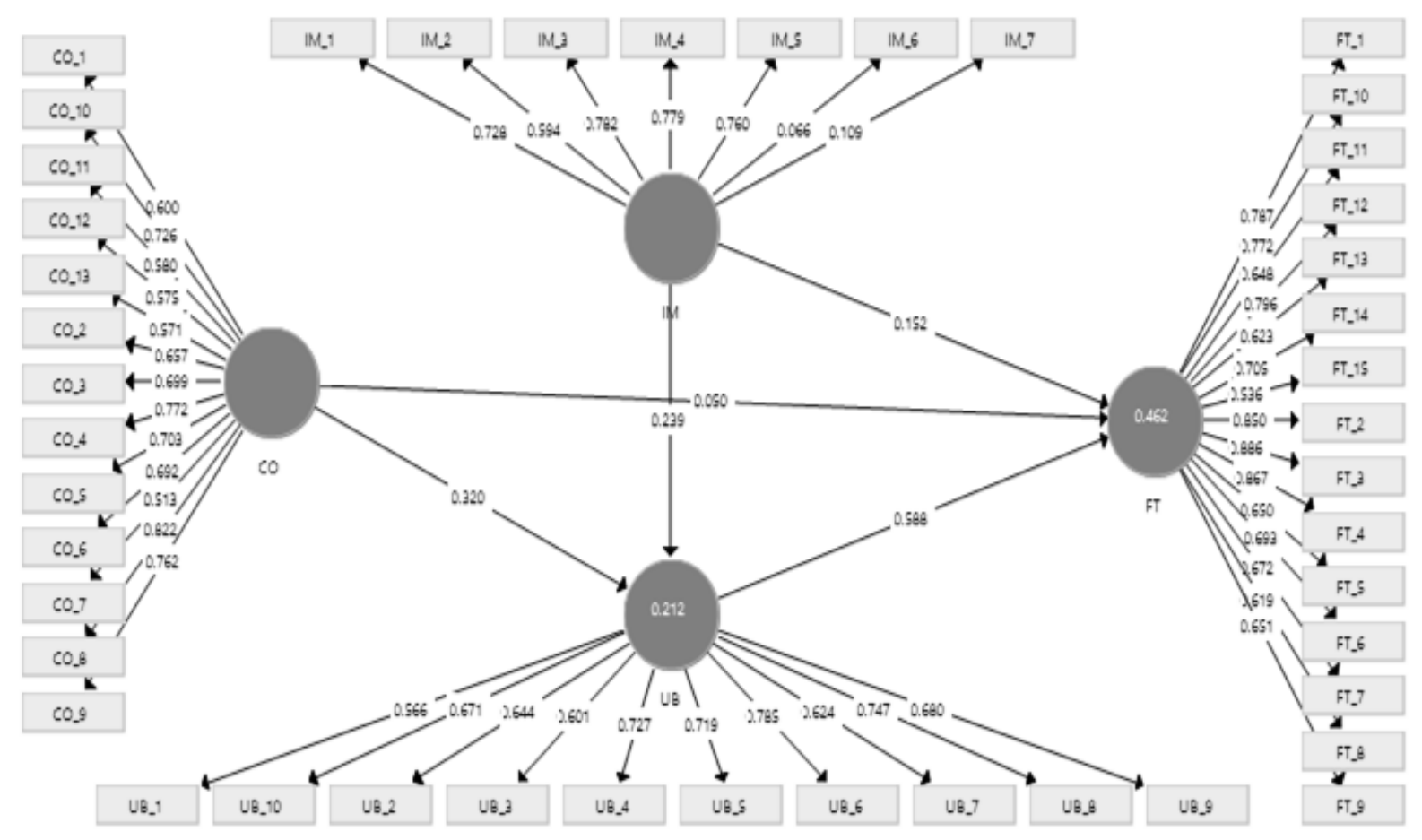

Gambar 1

Sumber: Data primer yang diolah

Diagram Jalur Disertai Nilai Loading Factor 


\section{Hasil Uji Outer Model}

Convergent validity dari model pengukuran reflektif indikator dinilai berdasarkan korelasi antara item score atau component score yang diestimasi dengan software SmartPLS. Ukuran reflektif indi vidual dikatakan berkorelasi jika lebih tinggi dari 0,70 dengan konstruk yang diukur. Namun, untuk penelitian tahap awal dari pengembangan skala pengukuran nilai loading 0,50 sampai 0,60 dianggap sudah cukup memadai (Ghozali, 2015). Dalam penelitian ini, batas loading factor yang digunakan sebesar 0,5 .

Berdasarkan hasil pengolahan data yang tertera pada Gambar 1, terdapat dua indikator yang memiliki nilai loading factor kurang dari 0,50, antara lain IM_6, dan IM_7. Oleh karena itu, indikator tersebut harus dikeluarkan dari model.

\section{Tabel 1}

Composite Reliability dan Cronbach Alpha

\begin{tabular}{lcc}
\hline \hline & $\begin{array}{c}\text { Composite } \\
\text { Reliability }\end{array}$ & $\begin{array}{c}\text { Cronbach } \\
\text { Alpha }\end{array}$ \\
\hline Competence & 0,914 & 0,897 \\
$\begin{array}{l}\text { Individual } \\
\text { Morality }\end{array}$ & 0,854 & 0,790 \\
$\begin{array}{l}\text { Unethical } \\
\text { Behavior }\end{array}$ & 0,895 & 0,868 \\
Fraud Tendency & 0,942 & 0,933 \\
\hline
\end{tabular}

Tabel 1 menunjukkan bahwa semua variabel telah memiliki nilai composite reliability di atas 0,70 sehingga dapat disimpulkan bahwa seluruh konstruk memenuhi kriteria reliabilitas. Selain itu, semua variabel juga sudah memiliki nilai cronbach alpha di atas 0,60 sehingga tingkat konsistensi jawaban responden dalam setiap konstruk memiliki reliabilitas yang baik.

\section{Hasil Uji Inner Model}

Pengujian inner model atau model struktural dilakukan untuk melihat hubungan antar konstruk berdasarkan teori substantif. Model struktural dievaluasi dengan menggunakan R-Square untuk konstruk depen- den, Stone-Geisser square test untuk predictive relevance, dan uji t serta signifikan dari koefisien parameter jalur struktural.

Tabel 2

Nilai $R$-Square

\begin{tabular}{lc}
\hline \hline & R-Square \\
\hline Unethical Behavior & 0,214 \\
Fraud Tendency & 0,459 \\
\hline
\end{tabular}

Sumber: Data primer yang diolah

Tabel 2 menunjukkan nilai $R$-Square untuk variabel unethical behavior diperoleh sebesar 0,214 dan untuk variabel fraud tendency diperoleh 0,459. Hasil tersebut menunjukkan bahwa variabel independen dalam penelitian ini secara simultan mampu menjelaskan variabel unethical behavior sebesar $21,4 \%$ dan sisanya $78,6 \%$ dijelaskan oleh variabel lainnya yang tidak dihipotesiskan dalam model. Kemudian, variabel fraud tendency mampu dijelaskan secara simultan oleh variabel independen sebesar 45,9\% dan sisanya $54,1 \%$ dijelaskan oleh variabel lainnya yang tidak dihipotesiskan dalam model. Nilai R-square untuk variabel unethical behavior dan fraud tendency termasuk dalam kategori lemah menuju moderat.

\section{Tabel 3}

Nilai Q-Square

\begin{tabular}{lc}
\hline & Q-Square \\
\hline Unethical Behavior & 0,085 \\
Fraud Tendency & 0,207 \\
\hline
\end{tabular}

Sumber: Data primer yang diolah

Pada Tabel 3 menunjukkan nilai $Q$ Square untuk variabel unethical behavior diperoleh sebesar 0,085 dan untuk variabel fraud tendency diperoleh 0,207. Hasil tersebut menunjukkan bahwa variabel unethical behavior memiliki nilai predictive relevance yang termasuk dalam kategori lemah menuju moderat, sedangkan variabel fraud tendency termasuk dalam kategori moderat menuju kuat. Berdasarkan uraian tersebut 
dapat disimpulkan bahwa variabel independen memiliki keterkaitan prediktif (predictive relevance) dengan variabel dependen dalam model penelitian ini.

\section{Hasil Uji Hipotesis}

Nilai t-statistik dibandingkan dengan ttabel yang ditentukan dalam penelitian ini, yaitu sebesar 1,981 di mana diketahui nilai df sebesar 116 (jumlah sampel dikurang dua: 118-2) dan $\alpha$ sebesar 0,05 (two tailed). Batasan untuk menerima dan menolak hipotesis yang diajukan adalah $\pm 1,981$, di mana apabila nilai t-statistik berada pada rentang nilai -1,981 dan 1,981 maka hipotesis akan ditolak atau dengan kata lain menerima hipotesis nol $\left(\mathrm{H}_{0}\right)$.

Tabel 4

Path Coeffiecents (Mean, STDEV, T-Value)

\begin{tabular}{lllccccc}
\hline \hline & & & $\begin{array}{c}\text { Original } \\
\text { Sampel } \\
(\mathbf{O})\end{array}$ & $\begin{array}{c}\text { Sample } \\
\text { Mean (M) }\end{array}$ & $\begin{array}{c}\text { Standard Deviation } \\
\text { (StDev) }\end{array}$ & $\begin{array}{c}\text { T-Statistic } \\
\text { (IO/stdev) }\end{array}$ & $\begin{array}{c}\mathbf{P} \\
\text { Value }\end{array}$ \\
\hline $\mathrm{CO}$ & $\rightarrow$ & UB & 0,320 & 0,327 & 0,086 & 3,739 & 0,000 \\
$\mathrm{IM}$ & $\rightarrow$ & UB & 0,242 & 0,257 & 0,088 & 2,754 & 0,006 \\
$\mathrm{CO}$ & $\rightarrow$ & FT & 0,055 & 0,053 & 0,067 & 0,818 & 0,414 \\
$\mathrm{IM}$ & $\rightarrow$ & FT & 0,140 & 0,142 & 0,094 & 1,498 & 0,135 \\
$\mathrm{UB}$ & $\rightarrow$ & FT & 0,589 & 0,592 & 0,064 & 9,261 & 0,000 \\
\hline
\end{tabular}

Sumber: Data primer yang diolah

Tabel 4 menunjukkan bahwa pengaruh competence terhadap unethical behavior sebesar 0,320 dan signifikan pada 0,05 $(3,739>1,981)$. Pengaruh individual morality terhadap unethical behavior sebesar 0,242 dan signifikan pada $0,05(2,754>1,981)$.

Pengaruh competence terhadap fraud tendency sebesar 0,055 dan tidak signifikan pada $0,05(0,818<1,981)$. Pengaruh individual morality terhadap fraud tendency sebesar 0,140 dan tidak signifikan pada $0,05(1,498<1,981)$. Pengaruh unethical behavior terhadap fraud tendency sebesar 0,589 dan signifikan pada $0,05(9,261>1,981$.

\section{Hasil Uji Efek Intervening}

Langkah pertama melakukan pengujian pengaruh tidak langsung variabel $X$ ke variabel $Y$ melalui variabel $M$, dengan rumus:

$$
S a b=\sqrt{ } b^{2} S a^{2}+a^{2} S b^{2}+S a^{2} S b^{2} .
$$

Langkah kedua melakukan pengujian untuk mengetahui signifikansi pengaruh tidak langsung dengan menghitung nilai $\mathrm{t}$ dari koefisien ab dengan rumus: $t=a b / S a b$.
Tabel 5

Hasil Uji Efek Intervening

\begin{tabular}{lllllc}
\hline \hline & & & & & t-Statistic \\
\hline $\mathrm{CO}$ & $\rightarrow$ & UB & $\rightarrow$ & FT & 3,432 \\
$\mathrm{IM}$ & $\rightarrow$ & UB & $\rightarrow$ & FT & 2,621 \\
\hline
\end{tabular}

Sumber: Data primer yang diolah

Hasil dari pengujian melalui uji sobel menunjukkan bahwa terdapat pengaruh intervening variabel unethical behavior pada pengaruh tidak langsung antara variabel competence dan individual morality dengan fraud tendency dikarenakan memiliki tstatistic lebih besar dari t-tabel yaitu 1,981.

\section{Pengaruh Competence terhadap Unethical Behavior}

Hasil dari pengujian yang telah dilakukan menunjukkan nilai t-statistic sebesar 3,739. Nilai tersebut lebih besar dari t-tabel 1,981, sehingga hipotesis pertama $\left(\mathrm{Ha}_{1}\right)$ diterima. Hasil penelitian ini menjelaskan bahwa competence yang dimiliki para staf keuangan perbankan syariah dan asuransi 
syariah mampu meminimalisir unethical behavior. Hal ini menggambarkan bahwa competence dapat mempengaruhi praktik dan perilaku kerja karyawan, sehingga competence yang dimiliki oleh seseorang akan mencegah unethical behavior dengan etika dan norma-norma yang berlaku. Selain itu, competence dibutuhkan untuk dapat memahami dan mempertimbangkan hal-hal yang bersifat etis dan tidak etis. Hasil penelitian ini sejalan dengan hasil penelitian Mondal (2013), Susanto (2016), dan Oktavia (2018) yang menjelaskan bahwa competence berpengaruh secara signifikan terhadap unethical behavior.

Hasil penelitian ini menjelaskan bahwa kompetensi yang dimiliki para staf keuangan perbankan syariah dan asuransi syariah mampu meminimalisir perilaku tidak etis. Kompetensi merupakan kombinasi antara pengetahuan, keterampilan, dan sikap yang tercermin melalui perilaku kerja yang dapat diamati, diukur, dan dievaluasi (Susanto, 2016). Dalam penelitian ini kompetensi diukur dengan kompetensi intelektual, kompetensi emosional, dan kompetensi sosial. Kompetensi intelektual atau yang juga sering disebut inteligensi umumnya diketahui sebagai kemampuan kognitif yang dimiliki seseorang untuk menyesuaikan diri secara efektif pada lingkungan yang kompleks dan dinamis serta dipengaruhi oleh faktor genetik (Trihandini, 2005). Kompetensi intelektual sangat dibutuhkan untuk dapat memahami dan mempertimbangkan hal-hal yang bersifat etis dan tidak etis (Jamaluddin dan Indriasari, 2011).

Kompetensi emosional juga memegang peranan penting untuk memprediksi perilaku seseorang (Tikollah et al., 2006). Emosi dan akal adalah dua bagian dari satu kesatuan, di mana kompetensi emosional adalah hubungan pribadi dan antarpribadi (Dewi dan Wirakusuma, 2018). Kompetensi emosional dibutuhkan untuk mengendalikan ego dalam diri seseorang (selfregulation). Tak hanya itu, kompetensi emosional juga mengarah pada kemampuan untuk me- ngenali diri sendiri (self awareness), motivasi (motivation), dan empati (emphaty) (Goleman, 2005). Oleh karenanya, kompetensi emosional akan mempengaruhi seseorang bersikap lebih etis dalam menyelesaikan suatu pekerjaan. Kompetensi sosial juga mempengaruhi seseorang dalam berperilaku. Kompetensi sosial merupakan karakter, sikap, atau kemauan seseorang untuk membangun simpul-simpul kerja sama dengan orang lain ketika menghadapi permasalahan di tempat kerja. Seseorang dengan kompetensi sosial yang baik biasanya memiliki sifat persuasif sehingga mampu mencegah orang lain untuk melakukan perbuatan tidak etis.

Hasil penelitian ini sesuai dengan attribute theory yang menjelaskan tentang perilaku seseorang, yang mana dapat disebabkan oleh atribusi internal seperti sifat, karakter, serta sikap yang dipengaruhi oleh kompetensi dan pengetahuan. Teori ini juga menjelaskan bahwa hanya dengan melihat sikap atau karakter seseorang maka dapat memprediksi perilaku seseorang dalam menghadapi situasi tertentu. Dengan begitu, kompetensi dapat mempengaruhi praktik dan perilaku kerja karyawan, sehingga kompetensi yang dimiliki oleh seseorang akan mencegah perilaku tidak etis dengan etika dan norma-norma yang berlaku.

\section{Pengaruh Individual Morality terhadap Unethical Behavior}

Hasil dari pengujian yang telah dilakukan menunjukkan nilai t-statistic sebesar 2,754. Nilai tersebut lebih besar dari t-tabel 1,981 , sehingga hipotesis kedua $\left(\mathrm{Ha}_{2}\right) \mathrm{di}-$ terima. Hasil penelitian ini menjelaskan bahwa individual morality yang dimiliki para staf keuangan perbankan syariah dan asuransi syariah mampu meminimalisir unethical behavior. Moralitas terjadi apabila seseorang sadar akan kewajiban dan tanggung jawab sosialnya, Dengan adanya tanggung jawab sosial diharapkan individu bertindak baik dan tidak melakukan penyimpangan. Hasil penelitian ini didukung oleh penelitian Pratiwi et al. (2016) dan Nisak 
dan Aeni (2017) yang menyatakan bahwa individual morality berpengaruh secara signifikan terhadap unethical behavior. Namun, hasil penelitian ini tidak sejalan dengan penelitian Yulianti et al. (2016) yang menunjukkan hasil bahwa individual morality tidak berpengaruh secara signifikan terhadap unethical behavior.

Hasil penelitian ini menjelaskan bahwa moralitas yang dimiliki para staf keuangan perbankan syariah dan asuransi syariah belum mampu meminimalisir perilaku tidak etis. Moralitas individu adalah suatu tata aturan yang mengatur pengertian baik atau buruk perbuatan manusia, sehingga dapat membedakan mana yang boleh dilakukan dan tidak boleh dilakukan (Yulianti et al., 2016). Moralitas terjadi apabila seseorang sadar akan kewajiban dan tanggung jawab sosialnya (Ariani et al., 2014). Dengan adanya tanggung jawab sosial diharapkan individu bertindak baik dan tidak melakukan penyimpangan (Yulianti et al., 2016). Perilaku tidak etis muncul ketika individu gagal memenuhi harapan dan tanggung jawab sosial tersebut (Nisak dan Aeni, 2017).

Dalam penelitian ini, tidak terdapatnya perbedaan antara individu yang memiliki tingkat moralitas tinggi maupun tingkat moralitas rendah dalam melakukan tindakan tidak etis disebabkan karena individu menganggap dirinya sudah berada pada tahap moralitas yang tinggi, sehingga perilaku tidak etis tidak lagi menjadi isu di antara para karyawan. Berdasarkan jawaban responden, staf keuangan perbankan syariah dan asuransi syariah meyakini bahwa setiap individu memiliki standar moralnya masingmasing, sehingga suatu tindakan yang bermoral dapat dianggap tidak bermoral oleh orang lain. Contohnya ketika seseorang mengambil sebuah tindakan atau keputusan atas dasar kepentingan perusahaan, yang mana dianggap sebagai sebuah tindakan yang bermoral karena mempertimbangkan kepentingan yang lebih universal. Namun ternyata dalam kepentingan tersebut terdapat dilema etik, misalnya karyawan dituntut untuk meningkatkan keuntungan perusahaan lewat cara-cara yang tidak etis, sehingga terdapat unsur relativisme dalam menilai standar moralitas individu. Hasil penelitian ini pun sesuai dengan attribute theory yang menjelaskan tentang perilaku seseorang, yang mana dapat ditinjau salah satunya atas dasar keunikan. Keunikan merupakan tingkatan di mana seseorang memiliki perilaku yang berbeda dari orang lain ketika menghadapi situasi yang serupa. Selain itu, perilaku seseorang tidak hanya dipengaruhi oleh atribusi internal, tetapi juga atribusi eksternal, contohnya tekanan situasi atau keadaan tertentu yang akan memberikan pengaruh terhadap perilaku seseorang. Maka dari itu, moralitas individu tidak berpengaruh secara signifikan terhadap perilaku tidak etis, karena adanya pengaruh atribusi eksternal, yakni tekanan yang dipicu oleh keamanan atas risiko pekerjaan.

\section{Pengaruh Competence terhadap Fraud Tendency}

Hasil dari pengujian yang telah dilakukan menunjukkan nilai t-statistic sebesar 0,818 . Nilai tersebut lebih kecil dari t-tabel 1,981 , sehingga hipotesis ketiga $\left(\mathrm{Ha}_{3}\right)$ ditolak. Hasil penelitian ini menjelaskan bahwa competence yang dimiliki para staf keuangan perbankan syariah dan asuransi syariah belum mampu meminimalisir fraud tendency. Hal ini dikarenakan kecurangan memiliki daya tarik bagi setiap individu. Cinta terhadap uang adalah salah satu kunci dasar untuk melakukan kecurangan (Tang \& Chiu., 2003). Oleh karena itu, competence dapat seketika runtuh ketika dihadapkan dengan kecintaan terhadap uang, sehingga muncul pembenaran untuk melakukan fraud tendency. Hasil penelitian ini didukung oleh penelitian Siregar dan Hamdani (2018) dan Novita (2019) yang menunjukkan bahwa competence tidak berpengaruh secara signifikan terhadap fraud tendency. Namun, hasil penelitian ini tidak sejalan dengan penelitian Dorminey et al. (2012) dan Oktavia (2018) yang menjelaskan bahwa competence berpengaruh secara signifikan terhadap fraud 
tendency. Hasil penelitian ini menjelaskan bahwa kompetensi yang dimiliki para staf keuangan perbankan syariah dan asuransi syariah belum mampu meminimalisir kecenderungan kecurangan, artinya tinggi atau rendahnya kompetensi yang dimiliki seseorang tidak berpengaruh terhadap kecenderungan kecurangan. Hal ini disebabkan karena kecurangan memiliki daya tarik tersendiri bagi setiap individu. Cinta terhadap uang adalah salah satu kunci dasar untuk melakukan kecurangan (Tang dan Chiu, 2003). Oleh karena itu, kompetensi dapat seketika runtuh ketika dihadapkan dengan kecintaan terhadap uang, sehingga muncul pembenaran atas tindakan tersebut.

Hasil penelitian ini sesuai dengan gone theory yang menjelaskan bahwa salah satu faktor yang mendorong seseorang melakukan kecurangan adalah greed atau keserakahan. Ketika seseorang memiliki sifat serakah, maka ia akan mengabaikan integritasnya dengan menyalahgunakan jabatan dan wewenangnya. Hal ini dapat dijelaskan dengan fenomena kecurangan yang terjadi pada industri perbankan syariah dan asuransi syariah. Kasus kecurangan di perbankan syariah dan asuransi syariah tidak hanya dilakukan oleh top management tetapi juga melibatkan karyawan. Hal ini menandakan bahwa setiap orang memiliki potensi untuk melakukan tindakan kecurangan, mulai dari lini staf sampai dengan level top management (Chapman and Lindner, 2016). Dengan demikian, tinggi atau rendahnya kompetensi yang dimiliki seseorang tidak mampu mencegah orang tersebut untuk melakukan kecenderungan kecurangan.

\section{Pengaruh Individual Morality terhadap Fraud Tendency}

Hasil dari pengujian yang telah dilakukan menunjukkan nilai t-statistic sebesar 1,498. Nilai tersebut lebih kecil dari t-tabel 1,981, sehingga hipotesis keempat $\left(\mathrm{Ha}_{4}\right)$ ditolak. Hasil penelitian ini menjelaskan bahwa individual morality yang dimiliki para staf keuangan perbankan syariah dan asuransi syariah belum mampu meminimalisir fraud tendency. Hal ini dapat dilihat dari sebagian besar jawaban responden yang menyatakan bahwa ia selalu mengikuti perintah atasan, demi menunjang karirnya. Selain dikarenakan adanya tekanan, belum diterapkannya aturan, kebijakan, dan prosedur yang mengacu pada etika membuat adanya kesempatan sehingga memunculkan rasionalisasi yang semakin mendorong karyawan untuk melakukan fraud tendency. Hasil penelitian ini sejalan dengan penelitian Lestari dan Prasetyono (2017) yang menjelaskan bahwa individual morality tidak berpengaruh secara signifikan terhadap fraud tendency. Namun, hasil penelitian ini tidak didukung oleh penelitian Yulianti et al. (2016) dan Pratiwi et al. (2016) yang menyatakan bahwa individual morality mempunyai pengaruh yang signifikan terhadap fraud tendency.

Hasil penelitian ini menjelaskan bahwa moralitas yang dimiliki para staf keuangan perbankan syariah dan asuransi syariah belum mampu meminimalisir kecenderungan kecurangan, artinya tidak terdapat perbedaan antara individu yang memiliki tingkat moralitas tinggi dengan tingkat moralitas rendah dalam melakukan kecurangan. Hal ini disebabkan karena seseorang menganggap dirinya sudah berada pada tahap moralitas yang tinggi dalam kehidupan sehari-sehari, namun tetap berbuat curang, karena adanya tekanan dan desakan dari pihak lain untuk melakukan kecurangan. Hal ini dapat dilihat dari sebagian besar jawaban responden yang menyatakan bahwa ia selalu mengikuti perintah atasan, demi menunjang karirnya.Tekanan timbul karena suatu kondisi atau keadaan mendesak yang memaksa atau mendorong seseorang melakukan tindakan kecurangan. Menurut Albrecht et al., (2012), tekanan tidak hanya terdiri ats tekanan finansial (financial pressures), tetapi juga tekanan akan kebiasaan buruk (vices pressures) ataupun tekanan yang berhubungan dengan pekerjaan (work- 
related pressures). Contohnya, muncul tekanan dari pimpinan untuk membuat laporan keuangan agar terlihat baik sehingga memicu dilema etik bagi karyawan untuk tetap mempertahankan laporan keuangan yang sesuai dengan prinsip moral yang ia miliki ataukah memenuhi keinginan pimpinan untuk memanipulasi laporan sehingga mendorong karyawan tersebut untuk melakukan kecurangan. Tak hanya itu, belum diterapkannya aturan, kebijakan, atau prosedur yang mengacu pada etika membuat adanya kesempatan sehingga memunculkan rasionalisasi yang semakin mendorong karyawan untuk melakukan kecenderungan kecurangan. Hasil penelitian ini sesuai dengan fraud pentagon theory yang menyebutkan bahwa adanya tekanan (pressure), kesempatan (opportunities), dan rasionalisasi (rasionalization) yang menjadi faktor pendorong individu dalam melakukan kecurangan. Oleh karena itu, individual morality tidak berpengaruh secara signifikan terhadap fraud tendency dikarenakan ada faktor lain seperti adanya tekanan dan kesempatan sehingga memunculkan rasionalisasi untuk melakukan kecenderungan kecurangan.

\section{Pengaruh Unethical Behavior terhadap Fraud Tendency}

Hasil dari pengujian yang telah dilakukan menunjukkan nilai t-statistic sebesar 9,261 . Nilai tersebut lebih besar dari t-tabel 1,981, sehingga hipotesis kelima ( $\left.\mathrm{Ha}_{5}\right)$ diterima. Hasil penelitian ini menjelaskan bahwa fraud tendency pada perbankan syariah dan asuransi syariah dipengaruhi oleh unethical behavior. Semakin seseorang melakukan unethical behavior, maka semakin tinggi pula fraud tendency yang dilakukan. Hasil penelitian ini sejalan dengan penelitian Pratiwi et al. (2016), Yulianti et al. (2016), Oktavia (2018) yang menjelaskan apabila lingkungan organisasi berperilaku tidak etis maka akan mendorong karyawannya untuk melakukan fraud tendency. Namun, hasil penelitian ini tidak didukung dengan penelitian Meiryani et al. (2019) dan Rae dan Subramaniam (2008) yang menjelaskan bahwa unethical behavior tidak berpengaruh secara signifikan terhadap fraud tendency.

Hasil penelitian ini sesuai dengan attribute theory, yang mana tidak hanya menjelaskan tentang faktor penyebab dari perilaku seseorang, tetapi juga menganalisis apa pengaruh dari perilaku tersebut di masa mendatang. Seseorang berperilaku tidak etis disebabkan karena faktor kemungkinan terdeteksi dan ukuran hukuman. Dua faktor tersebut pun mempengaruhi seseorang melakukan kecenderungan kecurangan. Semakin kecil peluang terdeteksinya perilaku tidak etis dan semakin ringan sanksi yang diberikan jika tindakan tersebut terdeteksi, maka seseorang akan semakin berani melakukan kecenderungan kecurangan. Hal tersebut juga sejalan dengan fraud pentagon theory yang menyebutkan bahwa arogansi (arrogance) menjadi salah satu risk factor dalam terjadinya kecenderungan kecurangan. Seseorang yang arogan memiliki sikap angkuh dan merasa perbuatannya tidak akan diketahui dan dirinya tidak akan menerima sanksi. Dengan demikian, unethical behavior mampu mendorong seseorang untuk melakukan fraud tendency.

\section{Pengaruh Competence terhadap Fraud Tendency melalui Unethical Behavior}

Hasil pengujian yang telah dilakukan menunjukkan nilai t-hitung signifikan pada 0,05 yaitu $3,432>1,981$, sehingga hipotesis keenam ( $\left.\mathrm{Ha}_{6}\right)$ diterima. Hal ini menunjukkan bahwa competence yang dimiliki para staf keuangan perbankan syariah dan asuransi syariah mampu mencegah unethical behavior sehingga dapat meminimalisir fraud tendency. Ketika seseorang memiliki competence yang memadai, maka akan menjauhkannya dari unethical behavior sehingga fraud tendency dapat dihindari. Dengan demikian, unethical behavior dapat dijadikan variabel intervening pada pengaruh tidak langsung antara competence dengan fraud tendency. Hasil penelitian ini didukung oleh penelitian Oktavia (2018) yang menyebutkan bahwa unethical behavior dapat memediasi pengaruh 
yang signifikan antara competence dengan fraud tendency. Kompetensi seseorang dapat diukur dengan kompetensi intelektual, kompetensi emosional, dan kompetensi sosial. Seseorang yang memiliki kompetensi intelektual akan dengan mudah memahami dan mempertimbangkan hal-hal yang bersifat etis dan tidak etis. Kompetensi emosional juga dibutuhkan guna mengendalikan ego dalam diri seseorang, sehingga mampu mempengaruhi seseorang bersikap lebih etis dalam menyelesaikan suatu pekerjaan. Selain itu, seseorang dengan kompetensi sosial yang baik akan memiliki sifat persuasif sehingga mampu mencegah orang lain untuk tidak melakukan tindakan tidak etis. Dengan dicegahnya perilaku tidak etis, maka kecenderungan kecurangan dapat dihindari.

Hasil penelitian ini sesuai dengan attribute theory yang menjelaskan tentang perilaku seseorang, yang mana salah satunya dapat disebabkan oleh atribusi internal antara lain sifat, karakter, serta sikap yang dipengaruhi oleh kompetensi dan pengetahuan. Teori ini juga menjelaskan bahwa hanya dengan melihat sikap atau karakter seseorang maka dapat memprediksi perilaku seseorang dalam menghadapi situasi tertentu. Indriani et al. (2016) menyebutkan bahwa kompetensi merupakan elemen utama yang diperlukan guna mencapai tujuan organisasi. Oleh karena itu, dibutuhkan kompetensi yang memadai guna mencegah seseorang berperilaku tidak etis dan berdampak pada menurunnya kecenderungan kecurangan sehingga tujuan organisasi dapat tercapai.

Pengaruh Individual Morality terhadap Fraud Tendency melalui Unethical Behavior

Hasil pengujian yang telah dilakukan menunjukkan nilai t-hitung signifikan pada 0,05 yaitu 2,621>1,981, sehingga hipotesis ketujuh $\left(\mathrm{Ha}_{7}\right)$ diterima. Hal ini menunjukkan bahwa individual morality yang dimiliki para staf keuangan perbankan syariah dan asuransi syariah dapat mencegah unethical behavior sehingga fraud tendency bisa diminimalisir secara signifikan. Individu dengan individual morality yang tinggi diharapkan tidak melakukan unethical behavior sehingga fraud tendency dapat dihindari. Hasil penelitian ini sejalan dengan penelitian Pratiwi et al. (2016) dan Fitri et al., (2016) yang menyatakan bahwa individual morality memiliki pengaruh yang signifikan terhadap fraud tendency melalui unethical behavior. Namun, hasil penelitian ini tidak didukung oleh penelitian Yulianti et al. (2016) yang menjelaskan bahwa tidak terdapat pengaruh yang signifikan antara individual morality dengan fraud tendency melalui unethical behavior. Junaidi dan Ubaidillah (2018), menjelaskan bahwa pentingnya moralitas individu dan pentingnya moralitas, karena moralitas akan mempengaruhi tindakan yang diambil oleh individu. Individu yang memiliki internalisasi norma moral yang tinggi lebih cenderung tidal melakukan fraud. Sebaliknya, individu yang memiliki internalisasi norma moral rendah lebih cenderung melakukan fraud.

Hasil penelitian ini menjelaskan bahwa unethical behavior belum mampu memediasi pengaruh tidak langsung antara individual morality dengan fraud tendency. Hal ini menunjukkan bahwa moralitas yang dimiliki para staf keuangan perbankan syariah dan asuransi syariah belum mampu mencegah perilaku tidak etis sehingga kecenderungan kecurangan belum dapat diminimalisir secara signifikan. Dengan demikian, unethical behavior belum dapat dijadikan variabel intervening pada pengaruh tidak langsung antara individual morality dengan fraud tendency. Hal ini disebabkan karena individu menganggap dirinya sudah berada pada tahap moralitas yang tinggi karena ia merasa sudah memiliki tujuan yang baik, seperti mendahulukan kepentingan perusahaan, sehingga perilaku tidak etis tidak lagi menjadi isu di antara para karyawan. Namun terkadang, tujuan tersebut bukanlah suatu hal yang baik, misalnya memanipulasi laporan keuangan demi keuntungan perusahaan. Hal tersebut memicu dilema etik 
akibat adanya tekanan yang dipicu oleh keamanan atas risiko kerja. Tekanan timbul karena suatu kondisi atau keadaan mendesak yang memaksa atau mendorong seseorang melakukan tindakan tidak etis yang berdampak pada terjadinya kecenderungan kecurangan. Tak hanya itu, belum diterapkannya aturan, kebijakan, atau prosedur yang mengacu pada etika membuat adanya kesempatan sehingga memunculkan rasionalisasi yang semakin mendorong karyawan untuk melakukan tindakan menyimpang. Jaijaram (2017) menyatakan nilainilai etika dapat mencegah tindakan fraud. Dia lebih lanjut menyatakan bahwa untuk menghindari potensi konflik kepentingan, code of conduct harus mendasari perilaku karyawan dalam menjalankan tugas yang ditugaskan kepada mereka. Nilai moral yang dipegang oleh karyawan dapat mencegah tindakan fraud. Nilai-nilai etika dapat menghalangi karyawan dari tindakan merugikan diri sendiri dan orang lain. Tindakan fraud tidak hanya merusak reputasi organisasi, tetapi juga reputasi perbankan syariah itu sendiri, dan berdampak pada tingkat kepercayaan dan kepuasan pelanggan serta kepercayaan investor pada perusahaan.

Hasil penelitian ini sesuai dengan attribute theory yang menjelaskan bahwa selain faktor internal, adanya faktor eksternal juga mempengaruhi seseorang dalam berperilaku, contohnya tekanan situasi atau keadaan tertentu yang dipicu oleh keamanan atas risiko pekerjaan. Teori ini juga menjelaskan bahwa dari perilaku tersebut dapat dianalisis dampaknya di masa mendatang. Tekanan situasi dan keadaan tertentu mampu mempengaruhi seseorang untuk melakukan tindakan tidak etis yang berdampak pada kecenderungan kecurangan, walaupun dirinya sudah merasa memiliki tingkat moralitas yang baik. Hasil penelitian ini juga sejalan dengan fraud pentagon theory yang menyebutkan bahwa adanya tekanan (pressure), kesempatan (opportunities), dan rasionalisasi (rasionalization) yang menjadi faktor pendorong individu dalam melakukan kecurangan. Oleh karena itu, individual morality belum mampu mencegah unethical behavior, sehingga fraud tendency belum dapat diminimalisir secara signifikan karena adanya faktor tekanan, kesempatan, dan rasionalisasi. Meskipun tidak berpengaruh secara signifikan, individual morality tetap dibutuhkan. Moralitas individu adalah suatu tata aturan yang mengatur pengertian baik atau buruk perbuatan manusia, sehingga dapat membedakan mana yang boleh dilakukan dan tidak boleh dilakukan (Yulianti et al., 2016). Moralitas terjadi apabila seseorang sadar akan kewajiban dan tanggung jawab sosialnya (Ariani et al., 2014). Dengan adanya tanggung jawab sosial diharapkan individu bertindak baik dan tidak melakukan penyimpangan (Yulianti et al., 2016).

\section{SIMPULAN}

Penelitian ini bertujuan untuk menguji faktor-faktor yang mempengaruhi fraud tendency melalui unethical behavior. Hasil penelitian ini menyimpulkan bahwa competence dan individual morality berpengaruh secara signifikan terhadap unethical behavior. Ketika seseorang memiliki competence yang memadai, maka akan menjauhkannya dari unethical behavior sehingga fraud tendency dapat dihindari. Kemudian, competence dan individual morality tidak berpengaruh secara signifikan terhadap fraud tendency. Namun, unethical behavior berpengaruh secara signifikan terhadap fraud tendency. Selanjutnya, individual morality yang dimiliki para staf keuangan perbankan syariah dan asuransi syariah dapat mencegah unethical behavior sehingga fraud tendency bisa diminimalisir secara signifikan. Individu dengan individual morality yang tinggi diharapkan tidak melakukan unethical behavior sehingga fraud tendency dapat dihindari. Hasil ini menunjukkan bahwa Competency dan Individual Morality mampu mencegah terjadinya unethical behavior, sehingga praktek-praktek fraud dapat dihindari. Sudah kewajiban bagi perbankan syariah dan asuransi syariah untuk terus meningkatkan kompetensi karyawannya, bukan hanya hardskill tetapi juga softskill, sehingga praktik-praktik fraud 
dapat dihindari. Hasil penelitian ini diharapkan mampu menjadi masukan yang berguna bagi dunia akademis dan juga dunia industri perbankan dan asuransi di Indonesia. Selain itu, hasil penelitian ini diharapkan mampu memberikan gambaran kepada perusahaan, regulator, dan praktisi tentang faktor-faktor penyebab fraud tendency. Hasil penelitian ini juga diharapkan mampu membantu perusahaan untuk terus meningkatkan kualitas sumber daya manusia dalam segi kompetensi, mendorong para karyawan untuk meningkatkan moralitas, memberikan kompensasi yang sesuai dengan beban kerja yang diemban para karyawan, membangun lingkungan yang lebih taat kepada aturan akuntansi, dan menerapkan praktik-praktik good corporate governance untuk menghindari terjadinya perilaku tidak etis, sehingga potensi terjadinya kecenderungan kecurangan dapat dicegah. Hasil penelitian juga memberikan pijakan bagi Perbankan Syariah agar membuat pedoman dan kebijakan etika dalam organisasi, yang berfungsi untuk memandu karyawan yang baru dipekerjakan. Pedoman dan kebijakan etika ini berfungsi sebagai pedoman perilaku karyawan dalam bertindak dan berprilaku profesional saat menjalankan tugas dan fungsinya sesuai dengan kewenangannya. Selain itu, untuk melindungi perusahaan dan pemangku kepentingan dari fraud, organisasi harus memahami fraud risk dan specific risk yang secara langsung atau tidak langsung berdampak pada perusahaan. Penilaian atas fraud risk, perlu disesuaikan dengan ukuran, kompleksitas, industri, dan tujuan organisasi dan harus diperbaharui secara berkala

Penelitian ini memiliki beberapa keterbatasan, antara lain: (1) instrumen dalam penelitian ini hanya terbatas pada penggunaan kuesioner, yang mana hanya mengukur persepsi pribadi; dan (2) dikarenakan adanya situasi pandemi Covid-19, penelitian ini tidak memungkinkan untuk menjangkau responden secara langsung. (3) Populasi dalam penelitian ini hanya difokuskan pada staf keuangan perbankan syariah dan asuransi syariah, tanpa melihat unsur-unsur lain yang terlibat secara tidak langsung pada unethical behavior dan fraud tendency.

\section{SARAN}

Berdasarkan keterbatasan penelitian di atas, berikut beberapa saran yang dapat menjadi pertimbangan bagi penelitian yang akan datang, penelitian dimasa datang disarankan menggunakan kuesioner disertai dengan wawancara dan identifikasi data lainnya sebagai bahan pertimbangan dalam menilai objektivitas tanggapan responden. Peneliti juga mengambil sampel yang lebih besar agar dapat menggeneralisasi hasil penelitian lebih baik. Selain itu penelitian selanjutnya disarankan untuk menambahkan variabel lain seperti locus of control, leadership style, motivation, dan integrity.

\section{DAFTAR PUSTAKA}

Adelin, V. dan E. Fauzihardani. 2013. Pengaruh Pengendalian Internal, Ketaatan pada Aturan Akuntansi dan Kecenderungan Kecurangan terhadap Perilaku Tidak Etis. WRA, 1(2): 259-276.

Albrecht, W. S., C. O. Albrecht, C. C. Albrecht, and M. F. Zimbelman. 2012. Fraud Examination (4th ed.), Mason, $\mathrm{OH}$ : South-Western Cengage Learning.

Ansori, A. F. 2017. Pengaruh Implementasi Good University Governance, Keefektifan Sistem Pengendalian Internal dan Ketaatan Aturan Akuntansi terhadap Kecenderungan Fraud pada PTKIN-BLU. Universitas Lampung.

Aranta, P. Z. 2013. Pengaruh Moralitas Aparat dan Asimetri Informasi terhadap Kecenderungan Kecurangan Akuntansi (Studi Empiris Pemerintah Kota Sawahlunto). Jurnal Akuntansi 1(1).

Ariani, K. S., L. S. Musmini, dan N. T. Herawati. 2014. Analisis Pengaruh Moralitas Individu, Asimetri Informasi, dan Keefektifan Sistem Pengendalian Internal terhadap Kecenderungan Kecurangan Akuntansi Di PDAM Kabupaten Bangli. E-Jurnal Ilmiah Mahasiswa Akuntansi 2(1). Undiksha. 
Arief, T. 2019. Bank BJB Sering Terjerat Kredit Fiktif, Ini Kata OJK. Diakses pada tanggal 17 Januari 2020 dari https://finansial. bisnis.com/read/20190320/90/902075/ bank-bjb-sering-terjerat-kredit-fiktif-inikata-ojk.

Artini, N. L. E. A., I. M. P. A. Adipura, dan N. T. Herawati. 2014. Pengaruh Budaya Etis Organisasi dan Efektivitas Pengendalian Internal terhadap Kecenderungan Kecurangan Akuntansi pada Satuan Kerja Perangkat Daerah (SKPD) Kabupaten Jembrana. E-Journal S1 Ak Universitas Pendidikan Ganesha 2(1).

Association of Certified Fraud Examiners (ACFE). (2020). Report to The Nations Global Study on Occupational Fraud and Abuse.

Chapman, D. W. dan S. Lindner. 2016. Degrees of Integrity: The Threat of Corruption in Higher Education. Studies in Higher Education 41 (2):247-68. https://doi.org/10.1080/03075079.2014. 927854.

Cohen, J., L. Pant, dan D. Sharp. 1993. A Validation and Extension of a Multidimensional Ethics Scale. Journal of Business Ethics 12: 13-26.

Dewi, T. K. dan M. G. Wirakusuma. 2018. Pengaruh Kecerdasan Intelektual, Kecerdasan Emosional, dan Kecerdasan Spiritual pada Perilaku Etis dengan Pengalaman sebagai Variabel Pemoderator. E-Jurnal Ekonomi dan Bisnis, Universitas Udayana: 2091-2115.

Dorminey, J., A. S. Fleming, M. Kranacher, dan R. A. Riley. 2012. The Evolution of Fraud Theory. American Accounting Association Issues in Accounting Education 27(2): 555-579.

Fauwzi, M. G. H. 2011. Analisis Pengaruh Keefektifan Pengendalian Internal, Persepsi Kesesuaian Kompensasi, Moralitas Manajemen terhadap Perilaku Tidak Etis dan Kecenderungan Kecurangan Akuntansi. Jurnal Akuntansi Universitas Diponegoro: 1-27.

Fauziah, F. E. dan M. Murharsito. 2019. The Effect of Money Ethics on Ethical
Attitudes with Religiosity as the Moderating Variable. Media Ekonomi dan Manajemen 34(1): 70- 84.

Fitri, Y., Nurazlina, dan Al Azhar. 2016. Pengaruh Keefektifan Sistem Pengendalian Internal, Ketaatan Aturan Akuntansi, Sistem Asimetri Informasi, dan Moralitas Individu Terhadap Kecenderungan Kecurangan Akuntansi dengan Perilaku Tidak Etis sebagai Variabel Intervening. JOM Fekon 3(1): 505-519.

Ghozali, I. 2015. Konsep, Teknik, dan Aplikasi Menggunakan Program Smart PLS 3.0 (Edisi 2). Salemba Empat, Universitas Diponegoro. Semarang.

Goleman, D. 2005. Introduction to the tenth anniversary edition. In Emotional intelligence. Bantam. New York.

Griffin, R. W. dan J. E. Ronald. 2006. Bisnis (Alih Bahasa Rd. Soemarnagara). Erlangga. Jakarta.

Guelpa, A., F. Marini, A. Du Plessis, R. Slabbert, dan M. Manley. 2017. Verification of Authenticity and Fraud Detection in South African Honey Using NIR Spectroscopy. Food Control, 73, 1388-1396. https:/ / doi.org/10.1016/j.foodcont.201 6.11.002.

Hasanudin, A. I. dan B. J. Pangayow. 2016. Analisis Faktor-Faktor yang Berpengaruh terhadap Kecenderungan Kecurangan Akuntansi dan Perilaku Tidak Etis (Studi Kasus pada SKPD di Kabupaten Keerom). Jurnal Akuntansi $\mathcal{E}$ Keuangan Daerah 11(1): 1-12.

Hardi, W. M., R. Anita, dan N. B. Zakaria. 2018. The Effect of Relativism Ethical Orientation, Personal Cost, and Moral Intensity on Internal Whistleblowing Intention: The Moderating Role of Organizational Commitment. International Journal of Engineering \& Technology 7: 122-125.

Heider, F. 1958. The Psychology of Interpersonal Relation. New York: Wiley.

Howarth, C. 2011. Representations, Identity and Resistance in Communication'. In: 
Hook, D., Franks, B. and Bauer, M. Eds. The Social Psychology of communication. London: Palgrave.

Idris, M. 2020. Belum Selesai Skandal Jiwasraya, Kini Muncul Masalah Asabri. Diakses pada tanggal 23 Agustus 2020 dari https://money.kompas.com/read/202 0/01/11/ 113539726/belum-selesaiskandal-jiwasraya-kini-munculmasalah-asabri? page $=$ all.

Ika, A. 2019. Kasus Pencurian di Bank Syariah Mandiri Terungkap, Pelakunya Karyawan Sendiri. Diakses pada tanggal 17 Januari 2020 dari https:/ / regional.kompas. com / read/2019/07/01/08170921/kasuspencurian-di-bank-syariah-mandiriterungkap-pelakunya-karyawansendiri.

Indriani, I., A. Suroso, dan S. Maghfiroh. 2016. Penerapan Konsep Fraud Diamond Theory dalam Mendeteksi Perilaku Fraud. Universitas Jendral Soedirman.

Jaijaram, P. 2017. Ethics in Accounting. Journal of Finance and Accountancy, 23.

Jamaluddin dan R. Indriasari. 2011. Pengaruh Kecerdasan Intelektual, Kecerdasan Emosional, dan Kecerdasan Spiritual terhadap Etika Mahasiswa Akuntansi Fakultas Ekonomi Universitas Tadulako. Jurnal Pamator 4(1): 40-47.

Junaidi dan M. Ubaidillah. 2018. The Influence of Compensation Suitability and Internal Control System to Fraud with Morality as a Moderating Variable. Jurnal Akuntansi Berkelanjutan Indonesia. 1(2): 226-235.

Jensen, C. dan H. Meckling. 1976. Theory of The Firm: Managerial Behavior, Agency Costs, and Ownership Sturcture. Journal of Financial Economics, 3: 305-360.

Kartika, H. 2018. Polemik Aset dalam Kepailitan Asuransi Syariah Mubarakah. Diakses pada tanggal 23 Agustus 2020 dari https://nasional.kontan.co.id/news/p olemik-aset-dalam-kepailitan-asuransisyariah-mubarakah.
Karyono. 2013. Forensic Fraud. CV Andi Offset. Yogyakarta.

Kusumastuti, N. R. dan W. Meiranto. 2012. Analisis Faktor-Faktor yang Berpengaruh terhadap Kecenderungan Kecurangan Akuntansi dengan Perilaku Tidak Etis sebagai Variabel Intervening. Diponegoro Journal of Accounting 1(1): 115.

Lestari, E. B. dan Prasetyono. 2017. The Factors Affecting Tendency of Fraud in Government Sector. Journal of Auditing, Finance, and Forensic Accounting 5(2): 6776.

Meiryani, Fenando, A. Susanto, dan D. L. Warganegara. 2019. The Effect of Accounting Information Systems Performance and Unthetic Behavior on Accounting Fraud. International Journal of Recent Technology and Engineering (IJRTE) 8(3): 2718-2725.

Meliana dan T. R. Hartono. 2019. Fraud Perbankan Indonesia: Studi Eksplorasi. Prosiding Seminar Nasional Pakar ke 2 Tahun 2019: 2.52.1-2.52.7.

Mondal, U. 2013. Integrity, Competency, and Ethical Behavior. International Journal of Marketing and Technology, 3(4): 188-196.

Nisak, S. K. dan I. N. Aeni. 2017. FaktorFaktor yang Berpengaruh terhadap Perilaku Tidak Etis Karyawan Bagian Akuntansi. Accounting Global Journal, 1(1): 56-64.

Novita, N. 2019. Teori Fraud Pentagon dan Deteksi Kecurangan Pelaporan Keuangan. Jurnal Akuntansi Kontemporer, 11(2): 64-73.

Nwayanwu, L. 2018. Accountants Ethics and Fraud Control in Nigeria: The Emergence of a Fraud Control Model. Journal of Accounting, Finance, and Auditing Studies 4(1): 130-150.

Oktavia, T. A. 2018. Determinan Kecurangan Berbasis Diamond Fraud dan Perilaku Tidak Etis sebagai Variabel Intervening pada Pemerintah Desa di Kabupaten Lumajang. Universitas Jember.

Pendse, S. G. 2012. Ethical Hazards: A Motive, Means, and Opportunity Ap- 
proach to Curbing Corporate Unethical

Behavior. J Bus Ethics 107: 265-279.

Prastiwi, D. 2020. Perjalanan Kasus Asabri, Merugi Lebih Rp10 T hingga Akan Ditelusuri Polri dan KPK. Diakses pada tanggal 23 Agustus 2020 dari https:// www.liputan6.com/news/ read/41565 60/perjalanan-kasus-asabri-merugilebih-rp-10-t-hingga-akan-ditelusuripolri-dan-kpk.

Pratiwi, T., D.P, E. Nur, dan Rofika. 2016. Pengaruh Penegakan Peraturan, Sistem Kompensasi, Ketaatan Aturan Akuntansi, dan Moralitas Aparat terhadap Kecenderungan Akuntansi dengan Perilaku Tidak Etis sebagai Variabel Intervening serta Pengaruhnya Terhadap Kinerja Instansi Pemerintah. JOM Fekon 3(1): 2327-2341.

Putri, P. A. A, dan S. A. Irwandi. 2016. The Determinants of Accounting Fraud Tendency. The Indonesian Accounting Review 6(1): 99-108.

Rae, K. dan N. Subramaniam. 2008. Quality of Internal Control Procedures: Antecedents and Moderating Effect on Organisational Justice and Employee Fraud. Managerial Auditing Journal 23(2): 104-124.

Said, J., M. M. Alam, M. Ramli, dan M. Rafidi. 2017. Integrating Ethical Values into Fraud Triangle Theory in Assessing Employee Fraud: Evidence from the Malaysian Banking Industry. Journal of International Studies 10(2):170-184.

Setiawan, S. 2018. The Effect of Internal Control and Individual Morality on The Tendency of Accounting Fraud. Asia Pacific Fraud Journal 3(1): 33- 41.

Siregar, M. I. dan M. Hamdani. 2018. Pengaruh Kesesuaian Kompensasi, Keefektifan Sistem Pengendalian Internal, Budaya Organisasi, dan Kompetensi terhadap Fraud (Studi pada Satuan Kerja Vertikal Kementerian Keuangan Provinsi Lampung). Jurnal Ekonomi Global Masa Kini Mandiri 9(1): 30-37.

Spencer, L. dan S. M. Spencer. 1993. Competence at Work, Models for Superior
Performance. Canada: John Wiley dan Sons, Inc.

Sujeewa, G. M. M, M. S. A. Yajid, A. Khatibi, S. M. F. Azam, dan I. Dharmaratne. 2018. The New Fraud Triangle Theory-Integrating Ethical Values of Employees. International Journal of Business, Economics and Law 16(5): 52-57.

Susanto, Y. 2016. Kompetensi, Kompensasi, dan Sanksi Hukum Pengaruhnya ter hadap Perilaku Aparatur dalam Pengadaan Barang atau Jasa di Kota Palembang. Journal Ecoment Global 1(1).

Tang, T. L. dan R. K. Chiu. 2003. Income, Money Ethic, Pay Satisfaction, Commitment, and Unethical Behavior: Is the Love of Money the Root of Evil for Hong Kong Employees? Journal of Business Ethics 46: 13-30.

Tikollah, M. Ridwan, I. Triyuwono, H. U. Ludigdo. 2006. Pengaruh Kecerdasan Intelektual, Kecerdasan Emosional dan Kecerdasan Spiritual terhadap Sikap Etis Mahasiswa Akuntansi, Proceeding SNAIX, Padang, 23-26 Agustus.

Toyudho, E. S. 2015. Deposito Rp29 Miliar Nasabah Bank Permata Digelapkan. Diakses pada tanggal 17 Januari 2020 dari https://nasional.tempo.co/read/67964 6/deposito-rp-29-miliar-nasabah-bankpermata-digelapkan/full\&view $=$ ok.

Trihandini, R. A. F. M. 2005. Analisis Pengaruh Kecerdasan Intelektual, Kecerdasan Emosi, dan Kecerdasan Spiritual Terhadap Kinerja Karyawan (Studi Kasus di Hotel Horison Semarang). Tesis Program Pascasarjana Magister Manajemen Universitas Diponegoro, Semarang. (diakses dari http://eprints. undip.ac.id/15539/1/Fabiola.pdf).

Wicaksono, A. P. dan D. Urumsah. 2017. Factors Influencing Employees To Commit Fraud in Workplace Empirical Study in Indonesian Hospitals." Asia Pacific Fraud Journal 1 (1): 1.

https://doi.org/10.21532/apfj.001.16. 01.01.01.

Winarto, Y. 2020. Asuransi Jiwa Syariah mampu kalahkan kinerja asuransi 
konvensional saat pandemi. https:// keuangan.kontan.co.id/news/asuransijiwa-syariah-mampu-kalahkan-kinerjaasuransi-konvensional-saat-pandemi.

Wiranata, I. G. A. B. 2005. Dasar-Dasar Etika dan Moralitas (Cetakan Kesatu). Citra Aditya Bakti. Bandung.

Yulianti, D. F., D. P E. Nur, dan Rofika. 2016. Pengaruh Moralitas Individu, Penegakan Hukum, Keadilan Distributif, Keadi- lan Prosedural, terhadap Kecenderungan Kecurangan Akuntansi dengan Perilaku Tidak Etis sebagai Variabel Intervening. JOM Fekon 3(1): 2177-2191.

Zuberi, O. dan S. Mzenzi. 2019. Analysis of Employee and Management Fraud in Tanzania. Journal of Financial Crime 26(2): 412-431. 